\title{
SOME RETESTS WITH THE STANFORD-BINET SCALE
}

\section{KATE GORDON}

\author{
Bureau of Children's Aid, California Department of Finance
}

In a recent issue of the Journal of Educational Psychology, (September, 1921), an important summary was made of several studies on the constancy of the Stanford-Binet IQ as shown by retests. The number of cases reported in the present paper is small, but each additional bit of evidence on so vital a question seems to be worth having. Moreover, my results, as far as they go, indicate a difference in the results of retests on the two sexes.

All of the original tests on the group here reported, and all of the retests were made by me. The children tested are all of one race-the Hebrew-and all are living in the same environment, an orphanage for Jewish children. The original tests were made in October, 1918, when a complete mental survey of the institution was in progress. In December, 1919, those were examined who had been admitted since the previous date. In August, 1921, another complete survey was made of the same institution. The results given below include all of the children who were tested twice in the course of this procedure, namely, 44 persons. For 34 children the interval between tests was approximately 2 years 10 months; for 9 children about 1 year 8 months, and for 1 child, it was 1 year 3 months.

The number being small, I give the individual records in Table I.

In the cases of Boy No. 23, and Boy No. 27 I believe that the loss in IQ is due to the fact that these boys, who passed most of the 18year-old tests of the scale, had no chance to earn a higher IQ because of the upper limit of the scale. On the other hand, Boy No. 17 also passed most of the 18-year-old tests, and had he been able to earn more, his gain in IQ would have been still greater.

The total distribution of changes in IQ is given in Table II. Their average is 6.8 .

In spite of the occasional large changes indicated in Table II there is on the whole a very substantial agreement between the results of the first and second tests of this group, the correlation being $r-0.84$, as shown in Table III.

A glance at Table I reveals the fact that most of the losses were with the girls and most of the gains with the boys. I can assign no 
TABLE I

\begin{tabular}{|c|c|c|c|c|c|c|c|c|}
\hline \multirow{2}{*}{$\begin{array}{c}\text { Boy } \\
\text { number }\end{array}$} & \multicolumn{2}{|c|}{ Age st Test I } & \multirow{2}{*}{$\begin{array}{c}\text { Intel hgence } \\
\text { quotient on } \\
\text { Test I }\end{array}$} & \multicolumn{2}{|c|}{ Age at Teat II } & \multirow{2}{*}{$\begin{array}{c}\text { Intalligence } \\
\text { quotient on } \\
\text { Test II }\end{array}$} & \multirow{2}{*}{$\begin{array}{l}\text { Points } \\
\text { lost }\end{array}$} & \multirow{2}{*}{$\begin{array}{l}\text { Points } \\
\text { gained }\end{array}$} \\
\hline & Years & Months & & Years & Months & & & \\
\hline 1 & 4 & 2 & 100 & 7 & 0 & 95 & 5 & \\
\hline 2 & 5 & 0 & 110 & 7 & 12 & 112 & . & 2 \\
\hline 3 & 5 & 8 & 100 & 7 & 4 & 91 & 9 & \\
\hline 4 & 6 & 4 & 95 & 8 & 0 & 94 & 1 & \\
\hline 5 & 7 & 3 & 89 & 8 & 11 & 83 & .. & 4 \\
\hline 6 & 8 & 5 & 85 & 10 & 1 & 98 & . & 13 \\
\hline 7 & 8 & 5 & 72 & 11 & 2 & 69 & 3 & \\
\hline 8 & 8 & 7 & 95 & 11 & 5 & 99 & .. & 4 \\
\hline 9 & 8 & 10 & 89 & 11 & 8 & 96 & .. & 7 \\
\hline 10 & 9 & 0 & 82 & 10 & 8 & 103 & .. & 11 \\
\hline 11 & 9 & 1 & 122 & 11 & 10 & 138 & .. & 16 \\
\hline 12 & 9 & 1 & 119 & 11 & 10 & 118 & 1 & \\
\hline 13 & 8 & $\theta$ & 95 & 12 & 7 & 87 & 8 & \\
\hline 14 & 0 & 10 & 92 & 11 & 6 & 93 & .. & 1 \\
\hline 15 & 9 & 10 & 94 & 12 & 8 & 81 & 3 & \\
\hline 16 & 10 & 4 & 100 & 13 & 2 & 99 & 1 & \\
\hline 17 & 10 & 7 & 125 & 13 & 5 & $141+$ & .. & 16 \\
\hline 18 & 10 & 7 & 94 & 13 & 5 & 106 & $\ldots$ & 12 \\
\hline 19 & 11 & 5 & 100 & 14 & 3 & 110 & .. & 10 \\
\hline 20 & 11 & 5 & 91 & 14 & 2 & 105 & .. & 14 \\
\hline 21 & 11 & 6 & 107 & 14 & 4 & 108 & .. & 1 \\
\hline 22 & 11 & 7 & 71 & 12 & 10 & 77 & $\ldots$ & 6 \\
\hline 23 & 11 & 10 & 130 & 14 & 7 & $122+$ & 8 & \\
\hline 24 & 12 & 0 & 79 & 14 & 10 & 83 & .. & 4 \\
\hline 25 & 12 & 7 & 98 & 15 & 5 & 111 & . & 13 \\
\hline 26 & 12 & 7 & 98 & 15 & 5 & 101 & . & 3 \\
\hline 27 & 12 & 11 & 126 & 15 & 10 & $117+$ & 9 & \\
\hline 28 & 13 & 0 & 92 & 14 & 8 & 99 & .. & 7 \\
\hline \multirow{2}{*}{$\begin{array}{c}\text { Girl } \\
\text { number }\end{array}$} & \multicolumn{2}{|c|}{ Age at Test I } & \multirow{2}{*}{$\begin{array}{c}\text { Intelligence } \\
\text { quotient on } \\
\text { Test I }\end{array}$} & \multicolumn{2}{|c|}{ Age at Teat II } & \multirow{2}{*}{$\begin{array}{c}\text { Intelligence } \\
\text { quotient on } \\
\text { Test II }\end{array}$} & \multirow{2}{*}{$\begin{array}{l}\text { Points } \\
\text { last }\end{array}$} & \multirow{2}{*}{$\begin{array}{l}\text { Points } \\
\text { gained }\end{array}$} \\
\hline & Years & Months & & Years & Months & & & \\
\hline 1 & 5 & 4 & 103 & 8 & 2 & 100 & 3 & \\
\hline 2 & 6 & 4 & 76 & 7 & 11 & 80 & . & 4 \\
\hline 3 & 6 & 4 & 78 & 7 & 11 & 78 & 1 & \\
\hline 4 & 8 & 2 & 114 & 10 & 11 & 110 & 4 & \\
\hline $\mathbf{5}$ & 8 & 3 & 109 & 11 & 0 & 106 & 3 & \\
\hline 6 & 8 & 5 & 109 & 11 & 3 & 104 & 5 & \\
\hline 7 & 8 & 11 & 121 & 11 & 8 & 118 & 3 & \\
\hline 8 & 8 & 11 & 95 & 11 & 9 & 81 & 14 & \\
\hline 9 & 10 & 7 & 83 & 13 & 5 & 75 & 8 & \\
\hline 10 & 11 & 6 & 103 & 14 & 4 & 91 & 12 & \\
\hline 11 & 11 & 8 & 89 & 14 & 6 & 80 & $\boldsymbol{\theta}$ & \\
\hline 12 & 11 & 10 & 92 & 14 & 8 & 89 & 3 & \\
\hline 13 & 12 & 10 & 101 & 15 & 8 & 98 & 3 & \\
\hline 14 & 12 & 10 & 84 & 15 & 8 & 84 & 10 & \\
\hline 15 & 13 & 2 & 116 & 16 & $\mathbf{0}$ & 83 & 23 & \\
\hline 16 & 13 & 7 & 97 & 16 & 5 & 103 & .. & $\theta$ \\
\hline
\end{tabular}


reason for this unless it be true that the girls come to an earlier stop in mental growth. Girl No. 15, who has a drop of 23 points seems an entirely normal child. Naturally one does not regard the matter as proved by 16 cases, but these are sufficiently arresting to suggest that it might be well for the records of boys and girls to be listed separately in reporting on the subject of retests. 